\title{
THE IMMUNOENDOCRINE THYMUS AS A PACEMAKER OF LIFESPAN
}

\author{
GYÖRGY CSABA* \\ Department of Genetics, Cell and Immunobiology, Semmelweis University, \\ Budapest, Hungary
}

(Received: 26 February 2016; accepted: 15 April 2016)

The thymus develops from an endocrine area of the foregut, and retains the ancient potencies of this region. However, later it is populated by bone marrow originated lymphatic elements and forms a combined organ, which is a central part of the immune system as well as an influential element of the endocrine orchestra. Thymus produces self-hormones (thymulin, thymosin, thymopentin, and thymus humoral factor), which are participating in the regulation of immune cell transformation and selection, and also synthesizes hormones similar to that of the other endocrine glands such as melatonin, neuropeptides, and insulin, which are transported by the immune cells to the sites of requests (packed transport). Thymic (epithelial and immune) cells also have receptors for hormones which regulate them. This combined organ, which is continuously changing from birth to senescence seems to be a pacemaker of life. This function is basically regulated by the selection of self-responsive thymocytes as their complete destruction helps the development (up to puberty) and their gradual release in case of weakened control (after puberty) causes the erosion of cells and intercellular material, named aging. This means that during aging, self-destructive and non-protective immune activities are manifested under the guidance of the involuting thymus, causing the continuous irritation of cells and organs. Possibly the pineal body is the main regulator of the pacemaker, the neonatal removal of which results in atrophy of thymus and wasting disease and its later corrosion causes the insufficiency of thymus. The co-involution of pineal and thymus could determine the aging and the time of death without external intervention; however, external factors can negatively influence both of them.

Keywords: immunity, hormonal system, thymus, pineal, lifespan regulation, death

*E-mail: csagyor@dgci.sote.hu 


\section{Introduction}

The thymus is an organ, which in adults contains a lot of fat; however, in infants, it is rich in cells seemingly up to adolescence after which its involution is gradually taking place. In adults, its largest weight is about $37 \mathrm{~g}$ and only $6 \mathrm{~g}$ in 75-year-olds. The thymus appeared about 500 million years ago [1] in cartilaginous fishes, together with the adaptive (acquired) immune system.

The human thymus was first observed by Galen of Pergamum (130-200 A.D.), who believed it as the seat of the soul because its location is near to the heart. He also observed that the weight of the organ is changing according to the age of a person. The name "thymus" was given by the ancient Greeks possibly by the name of a herb, as it is similar to a bunch of thyme.

The function of the thymus remained unknown for centuries. Vesalius (in 1600s) believed it as a thoracic cushion. A century later, it was believed as a regulator of the respiratory organ in fetal and neonatal stages. In 1777, William Hewson verified Galen's observations on the changing weight of the thymus and listed it among the lymphatic organs. Later, it was believed as an endocrine organ without knowing its hormone and effects. In 1961, Jacques Miller removed the thymus from newborn rats, which caused a dramatic effect on the condition and immunity of the animals [2], as a part of the lymphocyte population (later named $\mathrm{T}$ cells) disappeared and a fatal wasting disease developed. Further experiments cleared the central role of thymus in the development and function of the immune system. From this time, the thymus is registered as the most important (central) lymphoid organ. However, the change of mentality also brought to the front, the endocrine role of the gland, as the hormones produced by it and their effects on immune processes were massively studied and also sometimes such thymic hormones are also produced without primary immune role (atopic hormones). This means that at present, the thymus is listed as a lymphatic organ as well as an endocrine gland. Considering the neuroimmunoendocrine inter-relations, it is not surprising that in our present knowledge, the thymus is the only organ that performs two functions together.

As a central lymphoid organ, it produces mature $\mathrm{T}$ lymphocytes. The cells originated from the bone marrow reach the thymus, where they are selected and separated into two groups. One group can recognize self antigens (self-reactive T cells) and can destroy them; these cells are eliminated. However, some of them can avoid the negative selection in the thymus, and also thymus-generated T-reg cells inhibit them in the periphery [3]. The other group recognize foreign antigens and also can destroy them; these cells remain alive and are participating (together with the B-cells) in adaptive immunity. 
The epithelial part of the vertebrate thymus has its origin from the branchial region of the chordates, which is recapitulated during development. From this region, the thyroid and parathyroid glands as well as the thymus are developed as endocrine organs, in addition to the respiratory tract. However, the endocrine-like capacity of this latter is also conserved $[4,5]$. This epithelial part is responsible for self-hormone synthesis of the thymus, which is supplemented by the production of hormones that are mainly produced by other endocrine organs (atopic hormones). The two - lymphoid and endocrine - parts (function) of the thymus are in close connection directly or with the help of mediators [6]. The state and function of the organ is influenced by sympathetic and parasympathetic nerves as well as by the hormones of endocrine glands. In the frame of this regulation, the hypothalamopituitary-gonadal axis [7] and first of all the pineal body [8] seem to be the main regulators.

\section{Self-hormones of the thymus and their effects on immune cells}

As it was mentioned, for a long time, the thymus was classified as an endocrine gland without knowing its hormone. The discovery of its central role in the immune cell formation led to find the thymus-endogenous factors, which are responsible, or to help the selection of immune cells and the development of selfnon-self recognition. Numerous factors were prepared with different functions, but four of them seemed to be real and effective. They are thymulin, thymosin, thymopoietin (thymopentin), and thymic humoral factor (THF). These thymic hormones are synthesized and secreted by the epithelial cells [9]. Each hormone is produced by these cells, which also synthesizes cytokines, as IL-1 and 6, G-CSF, GM-CSF [9], which also have a role in thymocyte differentiation.

\section{Thymulin}

Thymulin, extracted from porcin thymus, is exclusively synthesized by the thymic epithelial cells. For its action, presence of zinc is necessary, which is coupled to the nonapeptide (Glu, Ala, Lys, Ser, Gln, Gly, Gly, Ser, Asn) and acts to the $\mathrm{T}$ cell differentiation $[10,11]$. It is strongly controlled by the neuroendocrine system. Binding to the specific receptor requests, residues 5-7 and the triggering site (residues 8 and 9) are needed for biological activity [10]. Thymulin is able to induce T-cell markers and normalizes the ratio between the helper and the suppressor T-cells [12]. There is a feedback control of thymulin secretion by the thymic epithelial cells [13]. 


\section{Thymosin}

Thymosins were prepared in 1966 by Goldstein and White [14] from a calf thymus, as functionally and biochemically distinct polypeptides. Its partially purified fraction 5 (TF5) was suitable for immunorestoration of pathological thymus (Di George syndrome and other thymic dysplasias). However, after this purification, TF5 contained at least 40 small polypeptides and their individual nature was not determined.

TF5, thymosin alpha 1 , and thymosin beta influence the lymphoid elements of the thymus (intrathymic effects including cyclic nucleotide level, migration inhibitory factor production, T-dependent antibody production, and cell surface maturation [15]). Thymosin alpha 1 is a synthetic, amino-acid terminal acetylated preparation, which has a pleiotropic action [16], enhancing $\mathrm{T}$ cell, dendritic cell, and antibody responses and inhibits steroid induced apoptosis in thymus. It is participating in the regulation of suppressor $T$ cell development [17].

Other thymosin fractions such as polypeptide beta 1, thymosin alpha 1, prothymosin alpha, parathymosin, and thymosin beta 4 were also prepared. However, they were not proved to be real thymic hormones as many other organs or cells synthesized them and did not influence thymus specific functions [18].

\section{Thymopoietin}

It is a polypeptide extracted from bovine thymus, composed of 49 amino acids. However, its effective part is TP5, which contains five amino acids namely arginine, lysine, asparagine, valine, and tyrosine (32-36 of thymopoietin). Consequently, instead of thymopoietin, a new name, thymopentin is used and the effects of it used to be studied. The pentapeptide is produced by the epithelial cells of the thymus and is participating in the immune regulation as well as $\mathrm{T}$ cell differentiation and influences - as an extrathymic effect - neuromuscular transmission [19]. Its effect seems to be dose dependent [20]. In in vitro conditions, it enhances $\mathrm{T}$-cell lineage proliferation and differentiation, mimicking thymus peptide environment in vivo [21]. In in vivo conditions, it induces the proliferation of lymphocyte precursors and their differentiation to $\mathrm{T}$ lymphocytes.

\section{Thymic humoral factor (THF)}

THF gamma 2, extracted from a calf thymus, is an octapeptide, and its amino acid sequence is Leu-Glu-Asp-Gly-Pro-Lys-Phe-Leu. It has all the biological activities of THF. This is a specific sequence that does not show homology with 
other thymic or non-thymic hormones [22]. A few nanograms of it enhances the frequency of mitogen responsive $\mathrm{T}$ cells in the thymus or the spleen, and positively influences $\mathrm{T}$ helper cell functions [23], targeting first of all the younger cell population [24]. After neonatal thymectomy, it stimulates proliferation of lymphoid cells [25]. Deficient $\mathrm{T}$ cell function is restored by it in human cases. Comparing a synthetic THF gamma 2 with thymosin alpha 1, THF's effect is 400-fold greater [26].

\section{Effect of thymic self-hormones on non-immune cells and functions}

Thymic hormones, in general, inhibit the changes provoked by aging [27], and helps to maintain the learning and memory capacities in the aging organism. Thymosin fraction 5 advanced vaginal opening and elevated oestrogen level in female mouse [28]. Thymic hormones can regulate the release of hormones from the pituitary gland [29] and thymic deprivation causes dysgenesis of pituitary anterior lobe [30], and thymic peptides influence hormone production of pituitary and gonads, e.g., thymulin enhances LH secretion and neonatal thymulin gene therapy prevents the reduction of circulating gonadotropin levels in athymic mice [31-33]. The proper functioning of the hypothalamo-pituitary-gonadal axis is dependent on thymic endocrine influences [34]. Thymosin F5 increased corticotropin, beta-endorphin, and cortisol level in monkeys [35], and thymectomy decreased the level of these hormones. Increasing thymulin level enhances pituitary gonadotropin level, acting directly on GnRH neurons [36]. In vitro conditions, the stimulatory effect of thymosin beta 4 on the production of LHRH and LH by hypothalamic and pituitary tissues was observed [34, 37]. Thymulin has a gonadotropin releasing $(\mathrm{GnRH})$ activity. Also studied in suspension of rat pituitary anterior lobes, thymulin had a dual role in the release of gonadotropins, which was dependent on the hormonal status of the donor's pituitary [38]. In combination with gonadotropin stimulation, thymulin increases testicular steroidogenesis $[39,40]$. Thymosin exercises influences on the secretion of beta endorphin, ACTH, LHRH, LH, and glucocorticoids [41, 42]. In young rats, TF5 inhibits TSH effect. Thymulin treatment in mice resulted in an earlier onset of puberty [43].

Non-self (atopic) hormones of the thymus

1. Biologically active glucocorticoids are synthesized in the thymus by the epithelial cells [44, 45] and the thymocytes have glucocorticoid receptors [46]. The receptors are already present in newborns with the same specificity as in adults. The cells not only produce but also incorporate glucocorticoids [47]. 
2. There is an intrathymic expression of some neuropeptides in the thymus as somatostatin, substance $\mathrm{P}$, vasointestinal peptide, calcitonin gene-related peptide, and neuropeptide Y $[48,49]$. Growth hormone $(\mathrm{GH})$ and prolactin are also produced by thymic epithelial cells and are present in thymocytes $[50,51]$, and the cells also have GH receptors. This latter can explain why is enhanced thymulin secretion of epithelial cells by it. Pituitary hormones - prolactin, luteinizing and follicle stimulating hormones, corticotropin releasing factor, oxytocin, and vasopressin - are also synthesized by the thymus cells [1, 52-55], and the cells have pituitary hormone receptors [56].

3. In the thymic cells, extrapineal melatonin can be found (synthesized) as well as melatonin synthesizing enzymes [57-59]. Both the thymic epithelial cells and thymocytes have MT1 and MT2 melatonin receptors [60].

Insulin is also synthesized in the thymus [61, 62]. Two-day starvation (stress) decreases the thymocyte count to $13 \%$ in ob/ob mice, which is restored by leptin treatment [63].

4. Oxytocin and vasopressin as well as insulin-like growth factor are synthesized by thymic epithelial cells [64].

5. Calcitonin is synthesized by the thymus [65] and also calcitonin receptors can be found [66]. Nuclear receptors for calcitriol are present in the medullar cells and Hassal's bodies [67].

6. The mentioned hormones are localized to different components of the thymus: (a) thymocytes contain serotonin and melatonin; (b) cortical cells synthesize only serotonin; and (c) mature medullar cells contain serotonin, melatonin, beta-endorphin, and gastrin. The expression of serotonin, somatostatin, and gastrin is localized in thymic epithelial cells, formatting Hassal's bodies [68].

Studying the hormone content of thymocytes, triiodothyronine (T3, regulated by TSH) [69-71], adrenocorticotropic hormone (ACTH), beta-endorphin [72], histamine, and serotonin [69] were found. T3 level is changing, and is dependent on the light-dark cycle [73].

\section{Effect of other (non-thymic-self) hormones on the thymus}

Neonatal pinealectomy causes typical wasting disease with the destruction of thymus $[74,75]$. Pinealectomy executed in adult rats decreases thymus weight, which is restored by melatonin treatment [76]. Long-time analysis also demonstrated the interrelation of pineal and thymus [77]. The thymic epithelial cells and thymocytes have melatonin receptors [78]. During aging, pineal peptides have geroprotective effect on thymus involution [79]. During acute stress, it prevents involution [80]. Melatonin strongly influences (elevates) the nocturnal thymic and 
serum level of thymosin alpha 1 and thymulin as well as the $24 \mathrm{hr}$ rhythm of them [81, 82]. Under stress conditions, melatonin prevents thymus involution [80].

$\mathrm{GH}$ regulates proliferation of thymic epithelial cells and thymocytes and also stimulates the secretion of thymic hormones [34, 51]. It also increases replenishment of the thymus, enhances thymocyte release from nurse cells, and increase thymocyte export as well as thymic hormone production [83]. Prolactin and GH enhance the extracellular matrix molecules in vitro [84]. Prolactin, $\mathrm{GH}$, and thyroid hormones enhance the production of thymulin [32, 85-88]. ACTH controls thymic growth [89]. GH, GH-releasing hormone, and luteinizing hormone releasing hormone enhance the proliferation of thymocytes [84]. Neuropeptides - in general - influences the T cell repertoire [90].

Glucocorticoids are participating in the deterioration of the immune system and mainly the thymus [91], and at the same time positively influence the extracellular matrix [84]. In thymus culture, progesterone increases the thymulin level [92]. Thymulin and thymosin alpha 1 production are inhibited by sex hormone treatments [93]. Ovariectomy increases thymus weight in mice [94].

Increased thymulin serum level was found in men in case of hyperthyroidism, hiperprolactinemia, and acromegaly. Thyroid hormones upregulate thymulin production $[32,85]$. Hypothyroidism (caused by drugs) provokes the involution of thymus [95], manifested in enhanced thymocyte development [96] and T3 production by it [71]. Insulin, oxytocin, gonadotropin, and EGF strongly influenced $\mathrm{ACTH}$, endorphin and $\mathrm{T} 3$ production by thymocytes, while ACTH synthesis was reduced [70] in in vitro experiments. Histamine and serotonin treatments in vitro radically reduced T3 content of thymocytes as well as the amine content of each other [97]. Insulin in vitro radically decreased the histamine and T3 synthesis of thymocytes and in vivo halved the amount of hormones [98]. Ghrelin helped the rejuvenation of involuting thymus [99].

Perinatal hormonal imprinting $[100,101]$ with T3 significantly increased the density of thymic glucocorticoid receptors in adult age [102]. A late steroid imprinting (with dexamethasone) decreased thymic glucocorticoid reception [103].

\section{Discussion}

The data mentioned above clearly demonstrate that the thymus has important hormonal regulatory roles, though one can forget this, because of the bright light of its central immune function. The thymus gland has self-hormones, which regulates $\mathrm{T}$ cell development as well as functions of other organs, and other hormones which are mainly produced by other endocrine glands. It has also receptors for both types of hormones. The lymphatic part of the organ is in the 
front of research presently as this is almost completely cleared and very important. In addition, it can be more easily studied. Whereas, the epithelial part of the organ develops earlier phylo- and ontogenetically, and the migration of lymphatic elements is taking place later under the effect of chemoattractants produced by the epithelium [104], as T cell precursors have receptors for them [105, 106]. The epithelial cells also produce factors (hormones), which help to select, differentiate, and mature the lymphatic cells and control apoptosis. They are also producing the non-self hormones, which are participating in the regulation, done by the endocrine system. When thymectomy is executed at neonatal age, wasting disease develops $[74,75]$ in which not only the thymus and the directly thymus-influenced lymphatic organs are touched but also the whole organism and the normal state can be partially restored by cell-free thymus extracts (hormones) [107]. Considering these facts, the thymus is a special organ in which both primarily endocrine elements and secondarily lymphatic elements are present cooperating with another, and from this aspect thymus is unique.

The thymus develops from the $3^{\text {rd }}$ and $4^{\text {th }}$ pharyngeal pouches, together with the parathyroids, and thyroid also have a branchial origin, with calcitonin producing $\mathrm{C}$ cells inside it and also the palatine tonsils, which similarly have some endocrine functions [108-110]. This part of the primitive gut, can be named with good reason to an endocrine area in which many overlapping specificities are present. The foregut-originated rat larynx, trachea, and oesophagus transplanted into the spleen incorporate $3 \mathrm{H}$ tyrosine and accumulate iodine similar to thyroid $[111,112]$, and thymus is taking up iodine $[113,114]$. In cultures of rat thymus, the proliferating cells take up iodine, as it is done by thyroid cells [114].

The "atopic" hormones, insulin, pituitary hormones, neurohormones, etc., are synthesized in the thymus and these hormones are transported by the emigrating $T$ cells to different parts of the body. This is a special form of transport, named "packed transport," when the hormone is not circulated freely in the blood, but finds the target addressed and together with the hormone also transports the factory, which can also produce it locally $[115,116]$. From this aspect, the hormone containing cells are similar to their mates formed in the bone marrow or somewhere in the organism in lymphatic tissues. However, the thymus is a site, where lymphocytes are selected "to be or not to be" and the selfresponsive cells are eliminated. Experiments demonstrate [62] that selective decrease or absence of insulin in the thymus leads to autoimmune (type 1) diabetes [117]. However, theoretically the loss or absence of other peptide hormones (e.g., ACTH, somatostatin, glucagon, LH, FSH, etc.) could cause autoimmune processes, though the effect of these have not been studied (except somatostatin, where in somatostatin receptor ablated mice also diabetes developed, similar to the insulin loss in thymus [118]). In this case, the primary role of 
the synthesis and the presence of these hormones in the thymus is the protection from self-aggression and the secondary is the hormone transport.

The lymphoid precursors are migrating from the bone marrow to the blood circulation reaching the thymus, where they will be selected. The function of selection is done by the nurse cells in the thymus, where more than $95 \%$ of the cells will be supplied with receptor which is the kiss of death [119], as they will be destroyed by the nurse cells themselves, in the thymus, or by the Treg-cells in the periphery.

It is generally believed that the involution of thymus starts at the age of puberty, whereas in man it starts from the first year of life [120, 121], and the first signs can be seen when 9 months old [122], followed by rapid (under 10 years and between 25 and 40 years) and slow (between 10 and 25 years and over 40 years) regressions. However, it becomes more conspicuous at the onset of puberty, and the organ almost disappears in the adult age (at age of 70 years only $10 \%$ remains). Nevertheless, the appearance and velocity of the process is individual. As this type of involution cannot be observed in case of other organs, it has to be suggested that thymus is the endogeneous determinator of the general (species) and individual life span. It is obvious that something is needed for the regulation of lifespan, as individual life cannot be infinite. The best solution for the problem if the regulator is in an organ, which is responsible for the healthy life and the same cells are involved in the extermination, which have been the helpers of life. Healthy life cannot be imagined without the selection of self-aggressive $\mathrm{T}$ lymphocytes, the marking and destruction of which is mainly taking place in the thymus, and it must be an endogenous regulator, which gradually reduces or later extinguishes the life, also without external interventions. The decrease, or later the loss of destruction of self-aggressive $\mathrm{T}$ cells seems to be suitable for this process, allowing the increase of the number and severity of autoimmune and infectious as well as degenerative diseases. This process is taking place during the aging. It is likely that the thymus is not alone in the regulatory process; it is influenced first of all by the pineal gland $[74,75]$ and secondarily by the hypothalamo-pituitary system [122]. The pineal seems to be the primary regulator, as it also has age-dependent degenerative alterations, and its removal in neonatal age completely destroys the thymus, and the thymus-dependent immune system [74, 75, 77, 123, 124]. Later removal of the pineal also has aging promoting and delaying effects, giving life and death signals with the participation of thymus $[125,126]$. The effect of pineal to thymus could be done by pineal peptides [127] or melatonin. It seems likely a functional unity of pineal and thymus involution [79, 124, 128]. The functional unity is also supported by human experiments, when durable combined treatment with pineal and thymus peptides prolonged the lifespan [129].

Puberty is a phase of life in which the sexual apparatus becomes mature and this gives the possibility for reproduction; the propagation of genes for the 
following generation which is the most biologically crucial event. After that, the individual life is not so important from biological point of view. From evolutionary (biological) aspect, in wild conditions, 30 years of lifespan is enough for man to propagate genes and rear children, the extra 50 years, possible today in developed countries only a product of cultural evolution, and it is not reckoning biologically in the function of thymus $[130,131]$. It does not seem to be a chance event that thymic involution is coming into sight at puberty, as the involution is enhanced by sexual steroids, the enrichment of which also happens in puberty, so the life-span-influencing events are in a close connection with another.

The release of self-aggressive cells from the thymus runs parallel with the less efficient $\mathrm{T}$-cell development and reduced emigration of naive $\mathrm{T}$ cells $[132,133]$. However, thymus cell production and hormone synthesis are present up to death in traces [134]. This means that aging is a complex process in which self-destructive and non-protective immune activities are manifested to a greater extent combined with the rest of the normal thymic activity. Gender also intervenes, as immunosenescence is accelerated in men, related to women [135].

Considering the above mentioned possibilities, the thymus - under the control of pineal body - could work indeed as a pacemaker, which from birth to the onset of puberty gradually increases and adapts its weight and functions to the needs of the growing organism. This latter requests the highest destruction of selfaggressive cells. However, the normal development leads to the active function of testis and ovary, which produces sex-steroid hormones. From this time, the thymus gradually loses epithelial and lymphatic cells, and nurse cells are not able to select so efficiently the autoaggressive T lymphocytes; than earlier, the amount of thymic self-hormones and cytokines [136, 137] diminishes and less apoptosis will be executed. The graduality seems to be very important, as the quick release of selfaggressive $\mathrm{T}$ cells could cause the sudden collapse of the whole organism. The "dosing" of self-aggressive cells can wear down the organs and mechanisms, which could be named aging. The quantity of released self-aggressive cells could regulate the velocity of aging process, as down-running sand in the sand-glass.

The objective signals of immunosenescence are the qualitative and quantitative alterations (dysregulation) of immune cells [138, 139] and especially the decrease of naive T cells [139-143]. It is sometimes supposed as a consequence of recurrent antigenic stimulation and oxidative stress [144]; however, the central (thymic pacemaker) problem is more likely. Treg cell's insufficiency also can cause problems, as too much actions provoke the decrease of immunity, and the decrease of Treg functions results in the risk of autoimmunity [145].

The involution of thymus is only a part of the general involution taking place during aging. However, the involution of thymus not only a well observed aging phenomenon, but also - as it was mentioned - it could be a causing factor or 
regulator of the aging process. During aging starting with the end of adolescence, the thymus gradually loses its earlier character and with the progress of aging it becomes empty, filled with adipose tissue. In the periphery, the B cells are present in normal number, producing antibodies; however, these antibodies have weaker affinity (to antigens) and less protecting than that of younger animals. There is a strong loss of naive T cells [146, 147], and parallel with these changes, the lifespan of mature B cells is prolonged. The decreased thymic output of mature $T$ cells results in the compensatory overproduction and gush of premature $\mathrm{T}$ cells, the senescence of which is taking place soon [147]. There is a remodeling of the whole immune system, with the decline of the T-cell branch [146] parallel with the increase of NK cells. Immune memory remains untouched, however, self-aggressivity increases [148]. Mass of molecular aberrations is manifested both in the self-hormone producing epithelial cells and thymocytes [149]. Because of the failures of immunity and appearance of proinflammatory cytokines [122] chronic systemic inflammation appears. If these changes are strongly expressed, autoimmune diseases develop as lupus, Sjögren syndrome, etc.; however, coronary diseases, stroke, diabetes, Alzheimer's disease also occur. It is conceivable that the weak but continuous irritation by the self-aggressive immune cells cause the process, which is named aging. With the progressing age, the selective control of the thymus is gradually weakened and more and more self-recognizing cells are releasing. They attack their target cells, however do not kill them, but senselessly inhibit their function. This working, however, weakened function is manifested during aging, and the strengthening of the process in special direction is manifested in the mentioned autoimmune diseases. Considering this, thymus involution could be a pacemaker indeed, of the whole aging process and not a consequence of aging, but an initiator and regulator of it. However, external factors, as bad life conditions, overloading, poisoning, etc., can negatively influence the "physiological" aging, positively influencing factors are not known, only those which are able to prevent negative ones.

Epigenetic processes, methylation of cytosins in DNA, and methylation, acetylation, and phosphorylation of histones play an important role in the development and function of immune cells. Hormonal imprinting $[100,101]$ is an epigenetic process, when perinatally the receptor binding capacity and hormone synthesis is adjusted for life. This basically influences the behavior of immune cells. However, in comparison with other cells, immune cells are imprinted in the whole life $[115,116]$, as the imprinting is not age, but developmental stage dependent and these cells are developing during the whole life. Hormonal imprinting is able to interfere into the aging process, as there is a progressive loss of methylcytosine content, primarily within DNA-repeated sequences and in potential gene regulatory areas [150], and this is manifested in the change of gene expression of DNA methyltransferases as well, as in the alterations of the aging 
immune system [151, 152]. As the loss of epigenetic control is two magnitude greater than that of somatic mutations [153], it could be a rather important factor in the aging of the immune system and consequently of the whole organism.

On the basis of the above mentioned facts and theories, the immunoendocrine role of thymus is unquestionable. However, it seems to be difficult to include the role of endocrine part into the pacemaker theory. During the involution of thymus, the loss of lymphatic part is prominent; however, the decrease of epithelial part is also obvious. Parallel with this, the production of self-hormones (thymulin, thymosin, thymopoietin, and THF) decreases and this could have an important role in the reduction of the lymphatic part. However, extrathymic actions of these hormones are also decreased, less participating in the complex endocrine regulation [154].

\section{References}

1. Geenen, V., Bodart, G., Henry, S., Michaux, H., Dardenne, O., Charlet-Renard, C., Martens, H., Hober, D.: Programming of neuroendocrine self in the thymus and its defect in the development of neuroendocrine autoimmunity. Front Neurosci 7, 187 (2013).

2. Miller, J. F.: The discovery of thymus function and of thymus derived lymphocytes. Immunol Rev 185, 7-14 (2002).

3. Geenen, V.: Presentation of neuroendocrine self in the thymus: A necessity for integrated evolution of the immune and neuroendocrine systems. Ann N Y Acad Sci 1261, 42-48 (2012).

4. Csaba, G., Prohászka, J.: 131I uptake of one-day chicken endodermal organs. Acta Physiol Scad Sci Hu 51, 385-388 (1978).

5. Csaba, G., Nagy, S. U., Bombera, G., Mándics, R.: Iodine accumulating ability as generalized property of cells of endodermal origin. Endocrinol Exp 9, 121-126 (1975).

6. ThyagaRajan, S., Privanka, H. P.: Bidirectional communication between the neuroendocrine system and the immune system: Relevance to health and diseases. Ann Neurosci 19, 40-46 (2012).

7. Leposavic, G., Perisic, M., Pilipovic, I.: Role of gonadal hormones in programming of developmental changes in thymopoietic efficiency and sexual diergism in thymopoiesis. Immunol Res 52, 7-19 (2012).

8. Csaba, G.: Hormonal regulation: Morphogenetic and adaptive systems. Biol Rev 52, 295-303 (1977).

9. Savino, W., Santa-Rosa, G. L.: Histophysiology of thymic epithelial reticular cells. Arch Histol Jpn 45, 139-144 (1982).

10. Dardenne, M., Bach, J. F.: Thymulin: Biochemistry, biology and therapeutical applications. Mem Inst Osvaldo Cruz, 82, 1-8 (1987).

11. Reggiani, P. C., Morel, G. R., Cónsole, G. M., Barbello, C. G., Rodriguez, S. S., Brown, O. A., Bellini, M. J., Pléau, J.-M., Dardenne, M., Goya, R.: The thymusneuroendocrine axis: Physiology, molecular biology, and therapeutic potential of the thymic peptide thymulin. Ann N Y Acad Sci 1153, 98-106 (2009). 
12. Haddad, J. J., Saade, N. E.: Thymulin: An emerging anti-inflammatory molecule. Curr Med Chem 4, 333-338 (2005).

13. Cohen, S., Berrih, S., Dardenne, M., Bach, J. F.: In vitro regulation of the secretion of thymulin (STF) by human thymic epithelial cells. C R Seances Acad Sci III 297, 63-65 (1983).

14. Goldstein, A. L., Badamchian, M.: Thymosins: Chemistry and biological properties in health and diseases. Expert Opin Biol Ther 4, 559-573 (2004).

15. Bodey, B., Bodey, B. Jr., Siegel, S. E., Kaiser, H. E.: Review of thymic hormones in cancer diagnosis and treatment. Int J Immunopharmacol 22, 261-273 (2000).

16. Romani, L., Moretti, S., Fallarino, F., Bozza, S., Ruggeri, L., Casagrande, A., Aversa, F., Bistoni, F., Velardi, A., Garaci, E.: Jack of all trades: Thymosin alpha 1 and its pleiotropy. Ann N Y Acad Sci 1269, 1-6 (2012).

17. Goldstein, A. L., Cohen, G. H., Thurman, G. B., Hooper, J. A., Rossio, J. L.: Regulation of immune balance by thymosin: Potential role in the development of suppressor T-cells. Adv Exp Med Biol 66, 221-228 (1976).

18. Hannappel, E., Huff, T.: The thymosins. Prothymosin alpha, parathymosin, and betathymosins: Structure and functions. Vitam Horm 66, 257-296 (2003)

19. Goldstein, G., Audhya, T. K.: Thymopoietin to thymopentin: Experimental studies. Surv Immunol Res 4, 1-10 (1985).

20. Duchateau, J., Bolla, K.: Immunomodulation with thymopoietin: In vitro studies. Med Oncol Tumor Pharmacother 6, 19-23 (1989).

21. Zhu, M. X., Wan, W. L., Li, H. S., Wang, J., Chan, G. A., Ke, X. Y.: Thymopentin enhances the generation of T-cell lineage derived from human embryonic stem cells in vitro. Exp Cell Res 331, 387-398 (2015).

22. Burstein, Y., Buchner, V., Pecht, M., Trainin, N.: Thymic humoral factor gamma 2: Purification and amino acid sequence of an immunoregulatory peptide from calf thymus. Biochemistry 27, 4066-4071 (1988).

23. van Bekkum, D. W., Betel, I., Blankwater, M. J., Kruisbeek, A. M., Swart, A. C.: Biologic activities of various thymus preparations. Transplant Proc 9, 1197-1199 (1977).

24. Rotter, V., Trainin, N.: Effect of thymic hormone on the response of different lymphoid cell populations to T mitogens. Isr J Med Sci 13, 363-370 (1977).

25. Caso, L. V.: Some endocrine aspects of the thymus gland. Jpn J Med Sci Biol 29, 289-321 (1976).

26. Goso, C., Frasca, D., Doria, G.: Effect of synthetic humoral factor (THF-gamma 2) on $\mathrm{T}$ cell activities in immunodeficient ageing mice. Clin Exp Immunol 87, 346-351 (1992).

27. Labunets, I.: Immune-neuroendocrine interactions involving thymus and pineal gland in stem cell therapy of age-related diseases. Immunol End Met Agents Med Chem 15, 101120 (2015).

28. Allen, L. S., McClure, J. E., Goldstein, A. L., Barkley, M. S., Michael, S. D.: Estrogen and thymic hormone interactions in the female mouse. J Repr Immunol 6, 25-37 (1984).

29. Markovic, L.: Interaction involving the thymus and the hypothalamus-pituitary axis, immunomodulation by hormones. Srp Arh Celok Lek 132, 187-193 (2004).

30. Kinoshita, Y., Hato, E.: Cellular and molecular interactions of thymus with endocrine organs and nervous system. Cell Mol Biol 47, 103-117 (2001).

31. Sawino, W., Arzt, E., Dardenne, M.: Immunoneuroendocrine connectivity: The paradigm of the thymus-hypothalamus-pituitary axis. Neuroimmunomodulation 6, 126-136 (1999). 
32. Dardenne, M.: Role of thymic peptides as transmitters between the neuroendocrine and immune systems. Ann Med 31, 34-39 (1999).

33. Reggiani, P., Martines, E., Ferese, C., Goya, R., Console, G.: Morphological restoration of gonadotrope population by thymulin gene therapy in nude mice. Histol Histopathol 24, 729-735 (2009).

34. Dabrowski, M. P., Dabrowski, M. I., Stankiewicz, W.: The thymus in neuro-endocrineimmune network. Centr Eur J Immunol 36, 188-192 (2011).

35. Healy, D. L., Hodgen, G. D., Schulte, H. M., Chrousos, G. P., Loriaux, D. L., Hall, N. R., Goldstein, A. L.: The thymus-adrenal connection: Thymosin has corticotropin-releasing activity in primates. Science 222, 1353-1355 (1983).

36. Su, S., Sun, X., Zhou, X., Fang, F., Li, Y.: Effects of GnRH immunization on the reproductive axis and thymulin. J Endocrinol 226, 93-102 (2015).

37. Rabar, R. W., Miyake, A., Low, T. L., Goldstein, A. L.: Thymosin stimulates secretion of luteinizing hormone-releasing factor. Science 214, 669-671 (1981).

38. Hinojosa, L., Garcia, L., Dominguez, R., Romano, M. C., Damian-Matsumura, P. G., Castillo, L., Rosas, P.: Effects of thymulin and GnRH on the release of gonadotropins by in vitro pituitary cells obtained from rats in each day of estrus cycle. Life Sci 76, 795-804 (2004).

39. Wise, T.: In vitro and in vivo effects of thymulin on rat testicular steroid synthesis. J Steroid Biochem Mol Biol 66, 129-135 (1998).

40. Wise, T., Ford, J. J.: Effects of the thymic peptide thymulin on in vitro and in vivo testicular steroid concentrations in white composite and meishan boars. J Anim Sci 77, 2240-2251 (1999).

41. Covelli, V., Minno, I., Altamura, M., Decandia, P., Pellegrino, N. M., Marcuccio, C., Caradonna, L., Jirillo, E.: Role of thymic hormones in neuroimmunomodulation. Their use in patients with phobic disorders. Acta Neurol 13, 457-466 (1991).

42. Goya, R. G., Brown, O. A., Bolognani, E.: The thymus-pituitary axis and its changes during aging. Neuroimmunomodulation 6, 137-142 (1999).

43. Garcia, L., Hinojosa, L., Dominguez, R., Chavira, R., Rosas, P.: Effects of infantile thymectomy on ovarian functions and gonadotrophin-induced ovulation in prepubertal mice: Role of thymulin. J Endocrinol 166, 381-387 (2000).

44. Jondal, M., Pazirandeh, A., Okret, S.: Different roles for glucocorticoids in thymocyte homeostasis. Trends Immunol 25, 595-600 (2004).

45. Talabér, G., Jondal, M., Okret, S.: Extra-adrenal glucocorticoid synthesis: Immune regulation and aspects on local organ homeostasis. Mol Cell Endocrinol 380, 89-98 (2013).

46. Csaba, G., Inczefi-Gonda, Á.: Similarities and dissimilarities of newborn and adolescent rats in the binding capacity of thymic glucocorticoid receptors. Mech Ageing Dev 122, 327-334 (2001).

47. Csaba, G., Fülöp, A. K.: Localisation of $3 \mathrm{H}$-corticosterone inside thymocytes at different stages of ontogenetic development. J Submicr Cytol 19, 567-571 (1987).

48. Silva, A. B., Palmer, D. B.: Evidence of conserved neuroendocrine interactions in the thymus: Intrathymic expression of neuropeptides in mammalian and non-mammalian vertebrates. Neuroimmunomodulation 18, 264-270 (2011).

49. Fuller, P., Verity, K.: Somatostatin gene expression in the thymus. J Immunol 143, 10151017 (1989). 
50. Pankov, Y. A.: Growth hormone and a partial mediator of its biological action, insulin-like growth factor I. Biochemistry (Mosc) 64, 1-7 (1999).

51. Savino, W.: Neuroendocrine control of T cell development in mammals: Role of growth hormone in modulating thymocyte migration. Exp Physiol 92, 813-817 (2007).

52. Chaves, V. E., Tilelli, C. Q., Brito, N. A., Brito, M. N.: Role of oxytocin in energy metabolism. Peptides 45, 9-14 (2013).

53. Geenen, V., Legros, J. J., Franchimont, P., Baudrihaye, M., Defresne, M. P., Boniver, J.: The neuroendocrine thymus: Coexistence of oxytocin and neurophysin in the human thymus. Science 232, 508-511 (1986).

54. Aird, F., Clevenger, C. V., Prystowsky, M. B., Redei, E.: Corticotropin-releasing factor mRNA in rat thymus and spleen. Proc Natl Acad Sci U S A 90, 7104-7108 (1993).

55. Batanero, E., de Leeuw, F. E., Janen, G. H., Van Wichen, D. E., Schuurman, H. J.: The neural and neuro-endocrine component of the human thymus. II. Hormone immunoreactivity. Brain Behav Immun 6, 249-264 (1992).

56. Tan, D. Y., Peng, X. P.: Progress in prolactin receptor research. Sheng Li Ke Xue Jin Zhan 43, 17-23 (2012).

57. Acuna-Castroviejo, D., Escames, G., Venegas, C., Diaz-Casado, M. E., Lima-Cabello, E., Lopez, L. C., Rosales-Corral, S., Reiter, R. J.: Extrapineal melatonin: Sources, regulation, and potential functions. Cell Mol Life Sci 71, 2997-3025 (2014).

58. Naranjo, M. C., Guerrero, J. M., Lardone, P. J., Carrillo-Vico, A., Carrascose-Salmoral, M. P., Jimenez-Jorges, S., Arellano, M. V., Leal-Noval, S. R., Leal, M., Lissen, E., Molinero, P.: Melatonin biosynthesis in the thymus of humans and rats. Cell Mol Life Sci 64, 781-790 (2007).

59. Srinivasan, V., Spence, D. W., Trakht, I., Pandi-Perumai, S. R., Cardinali, D. P., Maestroni, G. J.: Immunomodulation by melatonin: Its significance for seasonally occuring diseases. Neuroimmunomodulation 15, 93-101 (2008).

60. Carrillo-Vico, A., Guerrero, J. M., Lardone, P. J., Reiter, R. J.: A review of the multiple actions of melatonin on the immune system. Endocrine 27, 189-200 (2005).

61. Vafiadis, P., Bennett, S. T., Todd, J. A., Nadeau, J., Grabs, R., Goodyer, C. G., Wickramasinghe, S., Colle, S., Polychronakos, C.: Insulin expression in human thymus is modulated by INS VNTR alleles at the IDDM2 locus. Nat Genet 15, 289292 (1997).

62. Chentoufi, A. A., Polychronakos, C.: Insulin expression levels in the thymus modulate insulin-specific autoreactive T-cell tolerance. Diabetes 51, 1383-1090 (2002).

63. Howard, J. K., Lord, G. M., Matarese, G., Vendetti, S., Ghatel, M. A., Ritter, M. A., Lechler, R. I., Bloom, R.: Leptin protects mice from starvation-induced lymphoid atrophy increases thymic cellularity in ob/ob mice. J Clin Invest 104, 1051-1059 (1999).

64. Vacchio, M. S., Papadopoulos, V., Ashwell, D.: Steroid production in the thymus. Implications for thymocyte selection. J Exp Med 179, 1835-1846 (1994).

65. Galante, L., Gudmundsson, T. V., Matthews, E. V., Tse, A., Williams, E. D., Woodhouse, N. J. Y., MacIntyre, I.: Thymic and parathyroid origin of calcitonin in man. Lancet 2, 537538 (1968).

66. Marie, J. G., Wakkach, A., Coudray, A. M., Chastre, E., Berrih-Aknin, S., Gespach, C.: Functional expression of receptors for calcitonin gene-related peptide, calcitonin, and vasoactive intestinal peptide in the human thymus and thymomas from myasthenia gravis patients. J Immunol 15, 2103-2112 (1999). 
67. Stumpf, W. E., Downs, T. W.: Nuclear receptors for $1,25(\mathrm{OH})_{2}$ vitamin $\mathrm{D}_{3}$ in thymus reticular cells studied by autoradiography. Histochemistry 87, 367-369 (1987).

68. Kvetnoy, I. M., Polyakova, V. O., Trofimov, A. V., Yuzhakov, V. V., Yarilin, A. A., Kurilets, E. S., Mikhina, L. N., Sharova, N., Nikonova, M. F.: Hormonal function and proliferative activity of thymic cells in humans: Immunocytochemical correlations. Neuro Endocrinol Lett 24, 263-268 (2003).

69. Pállinger, É., Kovács, P., Csaba, G.: Presence of hormones (triiodothyronine, serotonin and histamine) in the immune cells of newborn rats. Cell Biol Int 29, 826-830 (2005).

70. Csaba, G., Pállinger, É.: In vitro effect of hormones on the hormone content of rat peritoneal and thymic cells. Is there an endocrine network inside the immune system? Inflamm Res 56, 447-451 (2007).

71. Csaba, G., Pállinger, É.: Thyrotropic hormone (TSH) regulation of triiodothyronine (T3) concentration in immune cells. Inflamm Res 58, 151-154 (2009).

72. Csaba, G., Kovács, P., Buzás, E., Mazán, M., Pállinger, É.: Histidine decarboxylase (HDC) knock out mouse immune cells have altered expression of ACTH, triiodothyronine and endorphin. Inflamm Res 56, 428-431 (2007).

73. Soutto, M., Guerrero, J. M., Osuna, C., Molinero, P.: Nocturnal increases in the triiodothyronine-thyroxine ratio in the rat thymus and pineal gland follow increases of type II 5'deiodinase activity. Int J Biochem Cell Biol 30, 235-241 (1998).

74. Csaba, G., Baráth, P.: Morphological changes of thymus and the thyroid gland after postnatal extirpation of pineal body. Endocrinol Exp 9, 59-67 (1975).

75. Csaba, G.: The pineal regulation of the immune system: 40 years since the discovery. Acta Microbiol Immunol Hung 60, 77-91 (2013).

76. Oner, H., Kus, I., Oner, J., Ogetürk, M., Ozan, E., Ayar, A.: Possible effects of melatonin on thymus gland after pinealectomy in rats. Neuroend Lett 25, 115-118 (2004).

77. Baráth, P., Csaba, G.: Histological changes in the lung, thymus and adrenal 1.5 years after pinealectomy. Acta Biol Acad Sci Hung 25, 123-126 (1974).

78. Mocchegiani, E., Malavolta, M., Costarelli, L., Giacconi, R., Piacenza, F., Lattanzio, F., Basso, A.: Is there a possible single mediator in modulating neuroendocrine-thymus interaction in ageing. Curr Aging Sci 6, 99-107 (2013).

79. Linkova, N. S., Poliakova, V. O., Kvetnoi, I. M., Trofimov, A. V., Sevostianova, N. N.: Characteristics of the pineal gland and thymus relationship in aging. Adv Gerontol 24, 38 42 (2011).

80. Pertsov, S. S.: Effect of melatonin on the thymus, adrenal glands, and spleen in rats during acute stress. Bull Exp Biol Med 141, 292-295 (2006).

81. Molinero, P., Soutto, M., Benot, S., Hmadcha, A., Guerrero, J. M.: Melatonin is responsible for the nocturnal increase observed in serum and thymus of thymosin alpha 1 and thymulin concentrations: Observations in rats and humans. J Neuroimmunol 103, 180-188 (2000).

82. Omar, S. H., Saba, N.: Melatonin, receptors, mechanism and uses. Syst Rev Pharmacy 1, 158-167 (2010).

83. Savino, W., Postel-Vinay, M. C., Smaniotto, S., Dardenne, M.: The thymus gland: A target for growth hormone. Scand J Immunol 55, 442-452 (2002).

84. van der Weerd, K.: Endocrine regulation of T-cell development and peripheral T-cell maturation. Doctor Theses, Erasmus Universitat, Rotterdam, 2013. 
85. Savino, W., Villa-Verde, D. M., Alves, L. A., Dardenne, M.: Neuroendocrine control of the thymus. Ann N Y Acad Sci 840, 470-479 (1998).

86. Dardenne, M.: Role of thymic peptides as transmitters between the neuroendocrine and immune system. Ann Med 31, 34-39 (1999).

87. Dardenne, M., Savino, W., Gagnerault, M. C., Itoh, T., Bach, J. F.: Neuroendocrine control of thymic hormonal production I. Prolactin stimulates in vivo and in vitro the production of thymulin by human and murine thymic epithelial cells. Endocrinology 125, 3-12 (1989).

88. Goya, R. G., Gagnerault, M. C., Sosa, Y. E., Bevilacqua, J. A., Dardenne, M.: Effects of growth hormone and thyroxine on thymulin secretion in aging rats. Neuroendocrinology 58, 338-343 (1993).

89. Talaber, G., Tuckerman, J. P., Okret, S.: ACTH controls thymocyte homeostasis independent of glucocorticoids. FASEB J 29, 2526-2534 (2015).

90. Savino, W., Dardenne, M.: Neuroendocrine control of thymus physiology. Endocr Rev 21, 412-443 (2000).

91. Calder, A. E., Hince, M. N., Dudakov, J. A., Chidgey, A. P., Boyd, R. L.: Thymic involution: Where endocrinology meets immunology. Neuroimmunomodulation 18, 281289 (2011).

92. Head, G. M., Downing, J. E. G., Brucker, C., Mentlein, R., Kendall, M. D.: Rapid progesterone actions on thymulin-secreting epithelial cells cultured from rat thymus. Neuroimmunomodulation 6, 31-38 (1999).

93. Seiki, K., Sakabe, K.: Sex hormones and the thymus in relation to thymocyte proliferation and maturation. Arch Histol Cytol 60, 29-38 (1997).

94. Nandedkar, T. D.: Immunoendocrine relationship-effect of ovariectomy on spleen and thymus in mouse. Indian J Exp Biol 30, 1101-1104 (1992).

95. AbouRabia, N., Kendall, M. D.: Hypothyroidism causes shrinking of the thymus gland. Cell Tissue Res 277, 1994.

96. Klein, J. R.: Physiological relevance of thyroid stimulating hormone receptor in tissues other than the thyroid. Autoimmunity 36, 417-421 (2003).

97. Csaba, G., Kovács, P., Pállinger, É.: In vitro effect of biogenic amines on the hormone content of immune cells of the peritoneal fluid and thymus. Is there a hormonal network inside the immune system? Cell Biol Int 31, 224-228 (2007).

98. Csaba, G., Kovács, P., Pállinger, É.: Influence of in vitro and in vivo insulin treatment on the hormone (histamine, serotonin, endorphin and triiodothyronine) content of thymus and spleen cells. Life Sci 78, 1034-1037 (2006).

99. Taub, D. D., Murphy, W. J., Longo, D. L.: Rejuvenation of aging thymus: Growth hormone-mediated and ghrelin-mediated signaling pathways. Curr Opin Pharmacol 10, 408-424 (2010).

100. Csaba, G.: Immunoendocrinology: Faulty hormonal imprinting in the immune system. Acta Microbiol Immunol Hung 61, 89-106 (2014).

101. Csaba, G.: The biological basis and clinical significance of hormonal imprinting, an epigenetic process. Clin Epigenetics 2, 187-196 (2011).

102. Csaba, G., Inczefi-Gonda, Á.: Effect of perinatal triiodothyronine (T3) treatment on thymic glucocorticoid and estrogen receptors and uterus estrogen receptors. Receptor selectivity during hormonal imprinting. Acta Physiol Hung 84, 19-23 (1996). 
103. Csaba, G., Inczefi-Gonda, Á.: Effect of late steroid imprinting of the thymus on the hormone binding capacity of thymocytic receptors in adulthood. Acta Physiol Hung $\mathbf{7 5}$, 195-199 (1990).

104. Champion, S., Imhof, B. A., Savagner, P., Thiery, J. P.: The embryonic thymus produces chemotactic peptides involved in the homing of hemopoietic precursors. Cell 44, 781-790 (1986).

105. Coltey, M., Jotereau, F. V., Le Douarin, N. M.: Evidence for a cyclic renewal of lymphocyte precursor cells in the embryonic chick thymus. Cell Differ 22, 71-82 (1987).

106. Wilkinson, B., Owen, J. J. T., Jenkinson, E. J.: Factors regulating stem cell recruitment to the fetal thymus. J Immunol 162, 3873-3881 (1999).

107. Trainin, N., Bejerano, A., Strahilevitch, M., Goldring, D., Small, M.: A thymic factor preventing wasting and influencing lymphopoiesis in mice. Isr J Med Sci 2, 549-559 (1966).

108. Varga, I., Pospisilova, V., Gmitterova, K., Galfiova, P., Polak, S., Galbavy, S.: The phylogenesis and ontogenesis of the human pharyngeal region focused on the thymus, parathyroid and thyroid glands. Neuro Endocrinol Lett 29, 837-845 (2008).

109. Weihe, E., Krekel, J.: The neuroimmune connection in human tonsils. Brain Behav Immun 5, 41-54 (1991).

110. Sapronov, M. S.: Participation of different parts of the tonsils and the hippocampus in the regulation of the pituitary-adrenal cortex system in rats. Probl Endocrinol 25, 51-56 (1979).

111. Csaba, G., Kiss, J., Nagy, S. U.: Comparative studies on the $125 \mathrm{I}$ uptake of the thyroid and thymus. Experientia 29, 357-358 (1973).

112. Csaba, G., Bombera, G., Mándics, R.: Provocation of biogenic amine production in the foregut entoderm by hormone induction. Z Mikrosk Anat Forsch 87, 351-356 (1973).

113. Connolly, L. P., Connolly, S. A.: Thymic uptake of radiopharmaceuticals. Clin Nucl Med 28, 648-651, (2003).

114. Csaba, G.: 3H-tyrosin incorporation by foregut entoderm as an additilonal proof of extraglandular presence of endocrine potencies. Z Mikrosk Anat Forsch 89, 640-644 (1975).

115. Csaba, G.: The immuno-endocrine system: Hormones, receptors and endocrine function of immune cells. The packed transport theory. Adv Neuroimm Biol 1, 71-85 (2011).

116. Csaba, G.: Hormones in the immune system and their possible role. A critical review. Acta Microbiol Immunol Hung 61, 241-260 (2014).

117. Fan, Z., Rudert, W. A., Grupillo, M., He, J., Sisino, G., Trucco, M.: Thymus specific deletion of insulin induces autoimmune diabetes. EMBO J 28, 2812-2824 (2009).

118. Wang, X. P., Norman, M. A., Brunicardi, F. C.: Somatostatin receptors and autoimmune mediated diabetes. Diabetes Metab Res Rev 21, 15-30 (2004).

119. Reyes Garcia, M. G., Tamayo, F. G.: The importance of the nurse cells and regulatory cells in the control of T lymphocyte responses. Biomed Res Int 2013, 352414 (2013).

120. Hale, P.: Histologic and molecular assesment of human thymus. Am Dian Pathol 8, 50-60 (2004).

121. Ventevogel, M. S., Sempowski, G. D.: Thymic rejuvenation and aging. Curr Opin Immunol 25, 516-522 (2013).

122. Aw, D., Silva, A. B., Palmer, D. B.: Immunosenescence: Emerging challenges for an ageing population. Immunology 120, 435-446 (2007).

123. Csaba, G., Rados, I., Wohlmuth, E.: Wasting disease and tetany following neonatal thymectomy. Acta Med Acad Sci Hung 29, 231-240 (1973). 
124. Polyakova, V. O., Linkova, N. S., Kvetnoy, I. M., Khavinson, V. K. H.: Functional unity of the thymus and pineal gland and study of the mechanism of aging. Bull Exp Biol Med 151, 627-630 (2011).

125. Pierpaoli, W.: Neuroimmunomodulation of aging. A program in the pineal gland. Ann $\mathrm{N}$ Y Acad Sci 840, 491-497 (1998).

126. Pierpaoli, W., Bulian, D.: The pineal aging and death program: Life prolongation in preaging pinealectomized mice. Ann N Y Acad Sci 1057, 133-144 (2005).

127. Linkova, N. S., Poliakova, V. O., Trofimov, A. V., Sevostianova, N. N., Kvetnoi, I. M.: Influence of peptides from pineal gland on thymus function at aging. Adv Gerontol 23, 543-546 (2010).

128. Jimenez-Jorge, S., Jimenez-Caliani, A. J., Guerrero, J. M., Naranjo, M. C., Lardone, P. J., Carrillo-Vico, A., Osuna, C., Molinero, P.: Melatonin synthesis and melatonin-membrane receptor (MT1) expression during rat thymus development? Role of the pineal gland. J Pineal Res 39, 77-83 (2005).

129. Khavinson, V. K. H., Morozov, V. G.: Peptides of pineal gland and thymus prolong human life. Neuroendocrinol Lett 24, 233-240 (2003).

130. DeMartinis, M., Franchesci, C., Monti, D., Ginaldi, L.: Inflamm-ageing and lifelong antigenic load as major determinants of ageing rats and longevity. FEBS Lett 579, 20352039 (2005).

131. Licastro, F., Candor, E. G., Porcellini, E., Colonna-Romano, G., Franchesci, C., Caruso, C.: Innate immunity and inflammation in aging: A key for understanding age related diseases. Immune Ageing 2, 8 (2005).

132. Taub, D. D., Longo, D. L.: Insights into aging and regeneration. Immunol Rev 205, 72-93 (2005).

133. Lynch, H. E., Goldberg, G. L., Chidgey, A., Van den Brink, M. R., Boyd, R., Sempowski, G. D.: Thymic involution and immune reconstitution. Trends Immunol 30, 366-373 (2009).

134. Kendall, M. D.: Have we underestimated the importance of the thymus in man? Experientia 40, 1181-1185 (1984).

135. Gubbels Bupp, M. R.: Sex, the aging immune system, and chronic disease. Cell Immunol 294, 102-110 (2015).

136. Rink, L., Cakman, I., Kirchner, H.: Altered cytokine production in the elderly. Mech Aging Dev 15, 199-209 (1998).

137. Andrew, P. D., Aspinall, R.: Age-associated thymic atrophy is linked to a decline in IL-7 production. Exp Gerontol 37, 455-463 (2002).

138. Solana, R., Mariani, E.: NK and NK-T cells in human senescence. Vaccine 18, 1613-1620 (2000).

139. Mocchegiani, E. E., Malavolta, M.: NK and NKT cell functions in immunosenescence. Cell 3, 177-184 (2004).

140. Linton, P., Thoman, M. L.: T cell senescence. Front Biosci 6, 248-261 (2001).

141. Appay, V., Sauce, D.: Naive T cells: The crux of cellular immune aging? Exp Gerontol 54, 90-93 (2014).

142. Wu, D., Meidani, N.: Age-associated changes in immune function: Impact of vitamin $\mathrm{E}$ intervention and the underlying mechanism. Endocr Metab Immune Disord Drug Targets 14, 283-289 (2014). 
143. Lazuardi, L., Jenewein, B., Wolf, A. M., Pfister, G., Tzankov, A., Grubeck-Loebenstein, B.: Age-related loss of naive $\mathrm{T}$ cells and dysregulation of $\mathrm{T}$ cell-B- cell interactions in human lymph nodes. Immunology 114, 37-43 (2005).

144. De Martinis, M., Franchesci, C., Monti, D., Ginaldi, L.: Apoptosis remodeling in immunosenescence: Implications for strategies to delay ageing. Curr Med Chem 14, 1389-1397 (2007).

145. Jagger, A., Shimojima, Y., Goronzy, J. J., Weyand, C. M.: Regulatory T cells and the immue aging process: A mini-review. Gerontology 60, 130-137 (2014).

146. Sansoni, P., Vescovini, R., Fagnoni, F., Biasini, C., Zanni, F., Zaniari, L., Telera, A., Lucchini, G., Passeri, G., Monti, D., Franchesci, C., Passeri, M.: The immune system in extreme longevity. Exp Gerontol 43, 61-65 (2008).

147. Grolleau-Julius, A., Ray, D., Yung, R. L.: The role of epigenetics in aging and autoimmunity. Clin Rev Allergy Immunol 39, 42-50 (2010).

148. Stacy, S., Krolick, K. A., Infante, A. J., Kraig, E.: Immunological memory and late onset of autoimmunity. Mech Aging Dev 123, 975-985 (2002).

149. Ortman, C. L., Dittmar, K. A., Witte, P. L., Le, P. T.: Molecular characterization of the mouse involuted thymus aberrations in expression of transcription regulators in thymocyte and epithelial compartments. Int Immunol 14, 813-822 (2002).

150. Issa, J. P.: Age-related epigenetic changes and the immune system. Clin Immunol 109, 103-108 (2003).

151. Yung, R. L., Julius, A.: Epigenetics, aging and autoimmunity. Autoimmunity 41, 329-335 (2008).

152. Casillas, M. A., Lopatina, N., Andrews, L. G., Tollefsbol, T. O.: Transcriptional control of the DNA methyltransferases is altered in aging and neoplastically-transformed human fibroblasts. Mol Cell Biochem 252, 33-43 (2003).

153. Bennet, T., Baker, P. E., Wilkowski, J., Burke, D. T.: Age-associated activation of epigenetically repressed genes in the mouse. Genetics 165, 2055-2062 (2003).

154. Hadden, J. W., Malec, P. H., Coto, J., Hadden, E. M.: Thymic involution in aging. Prospects for correction. Ann N Y Acad Sci 673, 231-239 (1992). 